\title{
Litoralimycins A and B, New Cytotoxic Thiopeptides from Streptomonospora sp. M2
}

\author{
Shadi Khodamoradi ${ }^{1,2}$, Marc Stadler ${ }^{2,3} \mathbb{C}^{-}$, Joachim Wink ${ }^{1,2, * \mathbb{C}}$ and Frank Surup ${ }^{2,3, * \mathbb{C}}$ \\ 1 Microbial Strain Collection, Helmholtz-Centre for Infection Research (HZI), Inhoffenstr. 7, \\ 38124 Braunschweig, Germany; shadi.khodamoradi@helmholtz-hzi.de \\ 2 German Centre for Infection Research (DZIF), partner site Hannover-Braunschweig, \\ 38124 Braunschweig, Germany; marc.stadler@helmholtz-hzi.de \\ 3 Microbial Drugs Department, Helmholtz-Centre for Infection Research (HZI), Inhoffenstr. 7, \\ 38124 Braunschweig, Germany \\ * Correspondence: joachim.wink@helmholtz-hzi.de (J.W.); frank.surup@helmholtz-hzi.de (F.S.); \\ Tel.: +49-351-6181-4223 (J.W.); +49-351-6181-4256 (F.S.)
}

Received: 28 April 2020; Accepted: 20 May 2020; Published: 26 May 2020

\begin{abstract}
Streptomonospora sp. M2 has been isolated from a soil sample collected at the Wadden Sea beach in our ongoing program aimed at the isolation of rare Actinobacteria, ultimately targeting the discovery of new antibiotics. Because crude extracts derived from cultures of this strain showed inhibitory activity against the indicator organism Bacillus subtilis, it was selected for further analysis. HPLC-MS analysis of its culture broth revealed the presence of lipophilic metabolites. The two major metabolites of those were isolated by preparative reversed-phase HPLC and preparative TLC. Their planar structures were elucidated using high-resolution electrospray ionization mass spectrometry (HRESIMS), 1D and 2D NMR data as new thiopeptide antibiotics and named litoralimycin A (1) and B (2). Although rotating frame nuclear Overhauser effect spectroscopy (ROESY) data established a $\mathrm{Z}$ configuration of the $\Delta^{21,26}$ double bond, the stereochemistry of C-5 and C-15 were assigned as S by Marfey's method after ozonolysis. The biological activity spectrum of $\mathbf{1}$ and $\mathbf{2}$ is highly uncommon for thiopeptide antibiotics, since they showed only insignificant antibacterial activity, but $\mathbf{1}$ showed strong cytotoxic effects.
\end{abstract}

Keywords: thiopeptide antibiotic; screening; structure elucidation; natural products; rare actinobacteria

\section{Introduction}

New antibiotics in general and new types of antibiotics in particular are urgently needed to counter the increasing number of pathogenic bacteria resistant against present antibiotics [1]. Traditionally, actinobacteria have been the most prolific sources of novel antibiotics scaffolds, because many of the most important antimicrobials, such as $\beta$-lactames, tetracyclines, rifamycins, aminoglycosides, macrolides and glycopeptides, were discovered from them [2]. However, high rates of rediscovery of known compounds are observed when screening traditional producers, and the discovery of new molecules is getting more and more challenging. Therefore, current screening programs concentrate on discovering and isolating rare genera of microorganisms. Rare actinobacteria are regarded as actinomycete strains whose isolation frequency is much lower than that of Streptomyces spp. isolated by conventional methods. These rare actinobacteria are assessed as a potential storehouse for novel antibiotics due to their unique potential to produce novel metabolites $[3,4]$.

The approach of utilizing rare organisms is accompanied by the screening of organisms from underexplored environments. Rare actinomycetes are widely distributed in terrestrial and aquatic 
ecosystems and the number of isolated genera and species is quickly increasing due to recently developed taxonomically selective isolation procedures, cultivation methods and genetic techniques [5]. We isolated the new strain Streptomonospora sp. M2 from a Wadden Sea sample collected at a beach near Cuxhaven, Germany, which is an underexplored environment. Since crude extracts of Streptomonospora sp. M2 showed inhibitory activity against Gram-positive indicator organisms including Micrococcus luteus, Staphylococcus aureus and Bacillus subtilis, the strain was selected for a detailed analysis of its bioactive secondary metabolites, yielding the isolation and structure elucidation of two new thiopeptide antibiotics (Figure 1) with an uncommon activity profile.

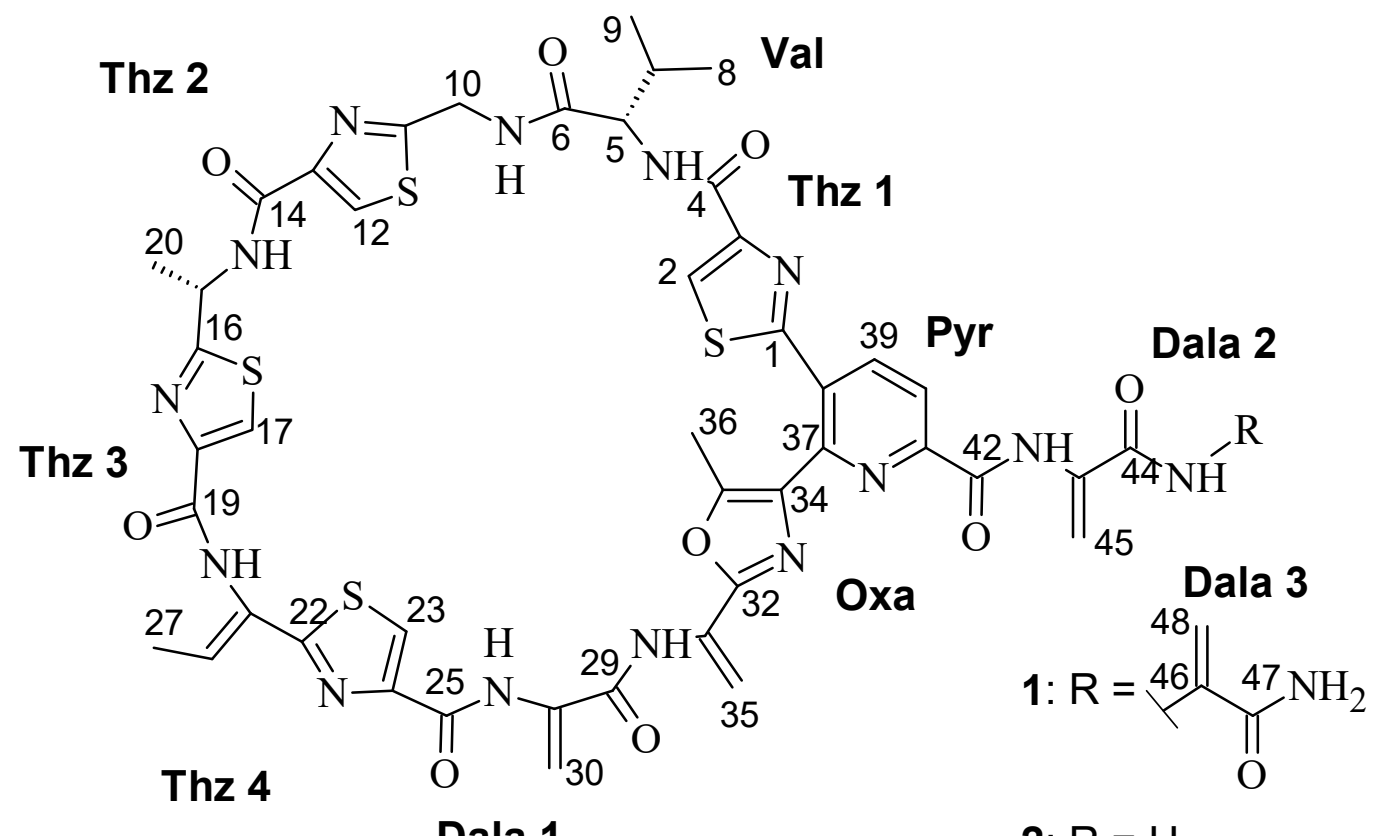

Dala 1

2: $\mathrm{R}=\mathrm{H}$

Figure 1. Chemical structure of $\mathbf{1}$ and 2.

\section{Results}

\subsection{Screening}

By a fractionation of the crude extracts in 96-well plates, it was possible to link the antibacterial activity to a region containing two major peaks (Figure S1). Consequently, we isolated 1 and 2 by preparative HPLC.

\subsection{Structure Elucidation}

Litoralimycin A (1) was isolated as a light-yellow oil. The molecular formula of $\mathrm{C}_{48} \mathrm{H}_{45} \mathrm{~N}_{15} \mathrm{O}_{10} \mathrm{~S}_{4}$ was derived from its high-resolution electrospray ionization mass spectrometry (HRESIMS) peak observed at $\mathrm{m} / \mathrm{z}$ 1120.2429. ${ }^{1} \mathrm{H}$ and heteronuclear single-quantum correlation spectroscopy (HSQC) NMR spectra indicated the presence of 5 methyls, 4 exomethylenes and 1 low-field aliphatic methylene, and 7 olefinic/aromatic as well as 3 aliphatic methines, in addition to 10 exchangeable protons bound to heteroatoms (Table 1). The number of exomethylenes in combination with the four sulfur atoms gave an early hint towards a thiopeptide. The ${ }^{13} \mathrm{C}$ spectrum indicated the presence of 9 additional carbonyls as well as 19 further olefinic carbons bearing no hydrogens. Based on correlation spectroscopy (COSY), total correlation spectroscopy (TOCSY) and heteronuclear multiple-bond correlation spectroscopy (HMBC) correlations, the planar thiopeptide structure, containing four thiazole (Thz), a valine (Val), an oxazole (Oxa), a pyridine (Pyr) and three dehydroalanine (Dala) units, was established (Figure 2). The rotating frame nuclear Overhauser effect spectroscopy (ROESY) correlation between $\mathrm{H}_{3}-27$ and 21-NH 
established the $\Delta^{21,26}$ double bond geometry as Z. Since thiazole amino acids racemize very easily during acid hydrolosis, the configuration of $\mathrm{C}-15$ was determined by ozonolysis of the aromatic ring for preservation of the chiral center followed by acid hydrolosis [6]. After ozonolysis, hydrolyzation and derivatization with FDAA, we detected L-Val and L-Ala according to Marfey's method [7]. Thus, both C-5 and C-15 are S-configured.

Table 1. NMR data $\left({ }^{1} \mathrm{H} 700 \mathrm{MHz},{ }^{13} \mathrm{C} 175 \mathrm{MHZ}\right)$ of $\mathbf{1}$ in DMSO- $d_{6}$.

\begin{tabular}{|c|c|c|c|c|c|c|c|}
\hline Unit & Pos & $\delta_{\mathrm{C}}$ & $\delta_{\mathrm{H}}$ & Unit & Pos & $\delta_{\mathrm{C}}$ & $\delta_{\mathrm{H}}$ \\
\hline \multirow[t]{4}{*}{ Thz 1} & 1 & $163.6, \mathrm{C}$ & & Dala 1 & 28 & 133.7, C & \\
\hline & 2 & 127.1, $\mathrm{CH}$ & $8.47, \mathrm{~s}$ & & $28 \mathrm{NH}$ & $\mathrm{NH}$ & 9.70, br s \\
\hline & 3 & $149.3, \mathrm{C}$ & & & 29 & $162.5, \mathrm{C}$ & \\
\hline & 4 & $159.9, \mathrm{C}$ & & & 30 & 104.5, $\mathrm{CH}_{2}$ & 5.74, br s \\
\hline \multirow[t]{6}{*}{ Val } & 5 & $58.2, \mathrm{CH}$ & $4.38, \mathrm{dd}(9.3,7.4)$ & & 30 & & 6.49, br s \\
\hline & $5 \mathrm{NH}$ & $\mathrm{NH}$ & $8.08, \mathrm{~d}(9.3)$ & Oxa & 31 & $129.0, C$ & \\
\hline & 6 & $170.9, \mathrm{C}$ & & & $31 \mathrm{NH}$ & $\mathrm{NH}$ & 9.78, br s \\
\hline & 5 & $30.6, \mathrm{CH}$ & $2.11, \mathrm{~m}$ & & 32 & $155.8, \mathrm{C}$ & \\
\hline & 8 & $19.3, \mathrm{CH}_{3}$ & $0.91, \mathrm{~d}(6.7)$ & & 33 & $150.0, \mathrm{C}$ & \\
\hline & 9 & $18.4, \mathrm{CH}_{3}$ & $0.88, \mathrm{~d}(6.7)$ & & 34 & 133.1, C & \\
\hline \multirow[t]{7}{*}{ Thz 2} & 10 & $40.2, \mathrm{CH}_{2}$ & $4.55, \mathrm{~m}$ & & 35 & $109.5, \mathrm{CH}_{2}$ & 5.64, br s \\
\hline & & & $\begin{array}{c}4.70, \mathrm{dd} \\
(16.0,6.4)\end{array}$ & & & & 5.43, br s \\
\hline & $10 \mathrm{NH}$ & $\mathrm{NH}$ & $8.95, \mathrm{t}(6.4)$ & & 36 & $11.4, \mathrm{CH}_{3}$ & $2.60, \mathrm{~s}$ \\
\hline & 11 & $168.6, \mathrm{C}$ & & Pyr & 37 & $147.6, \mathrm{C}$ & \\
\hline & 12 & $125.3, \mathrm{CH}$ & $8.25, \mathrm{~s}$ & & 38 & $130.8, \mathrm{C}$ & \\
\hline & 13 & 148.6, C & & & 39 & $141.1, \mathrm{CH}$ & $8.60, \mathrm{~d}(8.1)$ \\
\hline & 14 & $159.9, \mathrm{C}$ & & & 40 & $121.1, \mathrm{CH}$ & $8.25, \mathrm{~d}(8.1)$ \\
\hline \multirow[t]{7}{*}{ Thz 3} & 15 & $46.8, \mathrm{CH}$ & $5.44, \mathrm{~m}$ & & 41 & 149.0, C & \\
\hline & $15 \mathrm{NH}$ & $\mathrm{NH}$ & $8.74, \mathrm{~d}(8.2)$ & & 42 & 161.4, C & \\
\hline & 16 & $173.5, \mathrm{C}$ & & Dala 2 & 43 & 134.0, C & \\
\hline & 17 & $125.1, \mathrm{CH}$ & $8.29, \mathrm{~m}$ & & $43 \mathrm{NH}$ & $\mathrm{NH}$ & 10.5, br s \\
\hline & 18 & $148.7, \mathrm{C}$ & & & 44 & 161.9, C & \\
\hline & 19 & $159.2, \mathrm{C}$ & & & 45 & 104.0, $\mathrm{CH}_{2}$ & 5.82, br s \\
\hline & 20 & $20.5, \mathrm{CH}_{3}$ & $1.55, \mathrm{~d}(6.9)$ & & & & 6.61, br s \\
\hline \multirow[t]{8}{*}{ Thz 4} & 21 & $129.2, \mathrm{C}$ & & Dala 3 & 46 & 135.3, C & \\
\hline & $21 \mathrm{NH}$ & $\mathrm{NH}$ & 9.80, br s & & $46 \mathrm{NH}$ & $\mathrm{NH}$ & 9.54, br s \\
\hline & 22 & $167.3, \mathrm{C}$ & & & 47 & 165.1, C & \\
\hline & 23 & $125.0, \mathrm{CH}$ & $8.31, \mathrm{~s}$ & & $47 \mathrm{NH}$ & $\mathrm{NH}_{2}$ & 7.48, br s \\
\hline & 24 & $148.5, \mathrm{C}$ & & & & $\mathrm{NH}_{2}$ & 7.91, br s \\
\hline & 25 & $158.8, \mathrm{C}$ & & & 48 & $106.7, \mathrm{CH}_{2}$ & $5.96, \mathrm{~s}$ \\
\hline & 26 & $128.3, \mathrm{CH}$ & $6.52, \mathrm{~d}(6.9)$ & & & & $5.67, \mathrm{~s}$ \\
\hline & 27 & $14.1, \mathrm{CH}_{3}$ & $1.79, \mathrm{~d}(6.9)$ & & & & \\
\hline
\end{tabular}




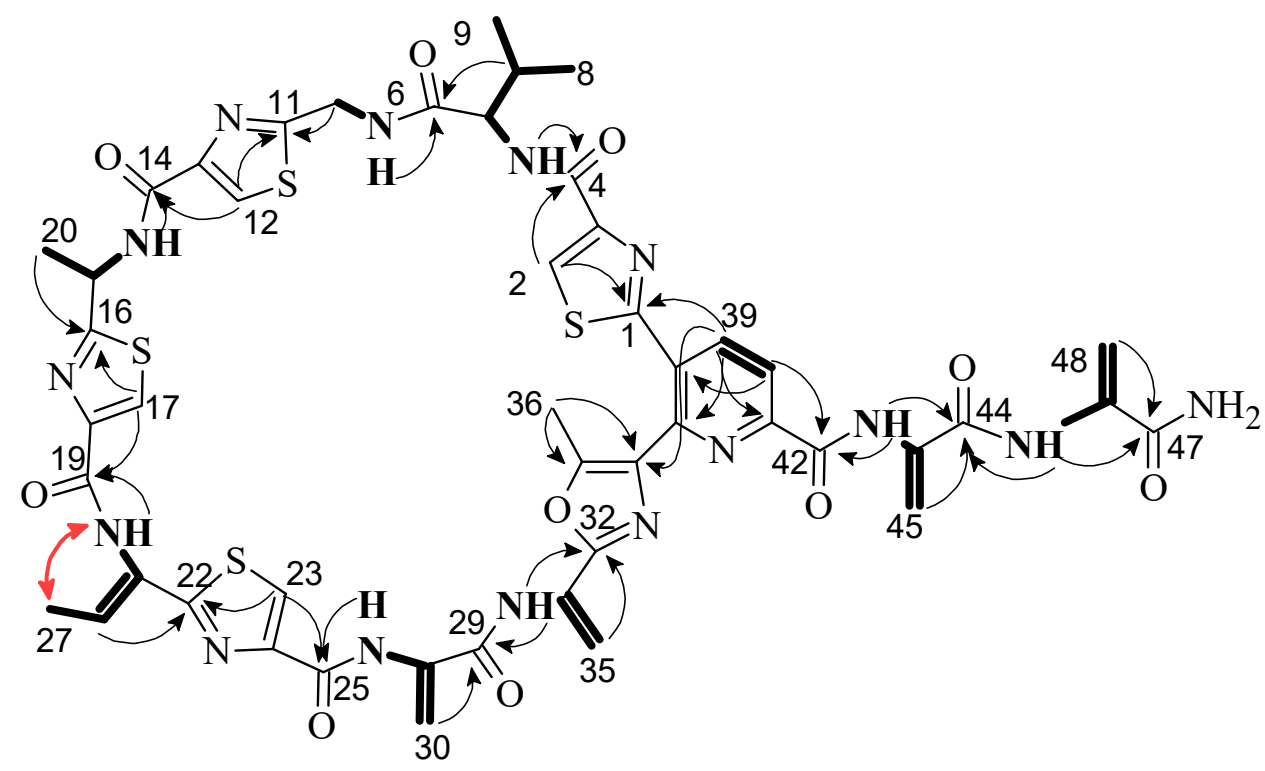

Figure 2. Selected ${ }^{1} \mathrm{H},{ }^{1} \mathrm{HCOSY}$ (bold lines), ${ }^{1} \mathrm{H},{ }^{13} \mathrm{C} \mathrm{HMBC}$ (black arrows) and ${ }^{1} \mathrm{H},{ }^{1} \mathrm{H}$ NOESY (red arrow) correlations of $\mathbf{1}$.

HRESIMS data of 2 gave a molecular formula of $\mathrm{C}_{45} \mathrm{H}_{42} \mathrm{~N}_{14} \mathrm{O}_{9} \mathrm{~S}_{4}$, implying the formal loss of a $\mathrm{C}_{3} \mathrm{H}_{3} \mathrm{NO}$ fragment compared to $\mathbf{1}$. The proton and carbon NMR spectra of 2 were highly similar to those of $\mathbf{1}$, with the key difference of the absence of a terminal dehydroalanin moiety. Therefore, the structure of $\mathbf{2}$ was established as identical to that of $\mathbf{1}$ with its side chain truncated by one dehydroalanin moiety.

\subsection{Bioactivity}

Litoralimycins A (1) and B (2) were evaluated for their minimum inhibitory concentration (MIC). Both compounds showed only a very weak activity against Staphylococcus aureus Newman and Bacillus subtilis DSM10 ${ }^{\mathrm{T}}$ with MIC values of $66.7 \mu \mathrm{g} / \mathrm{mL}$, respectively. No further effects were detected against any Gram-negative bacteria or fungi. (Table S1). However, cytotoxic effects against different cell lines were detected for $\mathbf{1}$ (Table 2). Litoralimycin B (2) with its truncated side chain showed much weaker cytotoxic activity.

Table 2. Cytotoxic activities of litoralimycins A (1) and B (2) against different cell lines. Values indicate $\mathrm{IC}_{50}$ in $\mu \mathrm{g} / \mathrm{mL}$.

\begin{tabular}{ccccccc}
\hline Compound & L929 & KB3.1 & MCF-7 & SKOV-3 & A431 & PC-3 \\
\hline $\mathbf{1}$ & 2.9 & 2.6 & 1.0 & 28 & 0.8 & 31 \\
\hline $\mathbf{2}$ & 24.0 & $/$ & n.t. ${ }^{1}$ & n.t. & n.t & n.t \\
\hline epothilon B [8] & 0.00082 & 0.000065 & 0.000048 & 0.000095 & 0.000045 & 0.0001 \\
\hline \multicolumn{7}{c}{${ }^{1}$ n.t.: not tested } \\
\end{tabular}

\section{Discussion}

Thiopeptides, or thiazolyl peptides, are highly modified sulfur-rich peptides of ribosomal origin. Over 100 chemical entities have been isolated in the last 50 years [9]. Of these entities, thiostrepton has been used as an FDA-approved active pharmaceutical ingredient for animals, and nosiheptide has been widely applied in veterinary antibiotics and food preservation. Their most characteristic feature is the central nitrogen-containing six-membered ring structure. Depending on the oxidation state of this central ring, thiopeptides can be classified into five different series [10]. The litoralimycins belong to the $d$ series, which is the most numerous subgroup, due to their trisubstituted pyridine moiety. 
Another option to group the thiopeptides is based on the ring size of the main macrocycle, since ring sizes of 26, 29, 32 and 35 atoms are found. Specifically, litoralimycins 1 and 2 belong to a small family of compounds with an oxazolyl-thiazolyl-pyridine fragment embedded in a 35-membered (13-residue) peptidyl macrocycle [11]. Other members of this family, which have highest structural similarity to $\mathbf{1}$ and 2, are the berninamycins, sulfomycin, thioplabin and TP-1161A. Common variations between members of this family are the exchange of thiazole by oxazole moieties, different methylation patterns and the size of the side chain (see Figure S3).

Most characterized thiopeptides display nanomolar potency toward Gram-positive bacteria by blocking protein translation, including the notorious pathogens methicillin-resistant Staphylococcus aureus (MRSA), vancomycin-resistant enterococci (VRE), and penicillin-resistant Streptococcus pneumoniae (PRSP). Their mechanism of action, acting as protein synthesis inhibitors, correlates with the size of the primary macrocycle: 29-atom macrocycles bind to elongation factor EF-TU, while 26and 32-atom macrocycles bind to the interface of protein L11 and the $23 \mathrm{~S}$ rRNA within the $50 \mathrm{~S}$ ribosomal subunit. The general molecular target of compounds with the largest 35-membered macrocycle remains unknown [10], although berninamycin was reported to target the 50S ribosome, in a similar manner to thiostrepton [11].

Using NMR and biochemical assays, a three-dimensional interaction model was developed, identifying L-Thr as a preserved region for the interaction with the ribosome/L11 complex [12]. This residue is missing for the litoralimycins, since $\mathbf{1}$ and $\mathbf{2}$ bear a L-Val at this position instead. In conformity with 1 and 2, radamycin also has a mutated residue with L-Val replacing L-Thr. In analogy to the litoralimycins, radamycin was devoid of any antibacterial activity in agar diffusion assays $[13,14]$. Nevertheless, radamycin showed a strong tip $A$ promoting activity. tip $A$ gene promotion, encoding the two thiostrepton-induced proteins (Tip) TipAL and TipAS. The latter serves as a defense mechanism for bacteria against thiopeptides. Since the tipA promotion activity was identified to be dependent on a dehydroalanine-containing tail close to the six-membered central scaffold [15], we expect the litoralimycins to be tipA activators.

Besides the aforementioned effects on bacteria, some thiopeptides show good anticancer activities [9]. For thiostrepton it was shown that this activity is based on its effect of reducing transcriptional activity of the forkhead box M1 (FOXM1). FOXM1 is an oncogenic transcription factor that is upregulated in a wide range of cancers. It is involved in the regulation of the cell cycle and promotes angiogenesis, as well as metastasis. Because treatment with thiostrepton had an effect on cell proliferation and cell-cycle progression in MCF-7 cells [16], and litoralimycins A (1) was strongly active against cell line MCF-7 in our test assay, FOXM1 might be the molecular target in common.

\section{Materials and Methods}

\subsection{General}

HRESIMS mass spectra were measured with an Agilent 1200 series HPLC-UV system in combination with an ESI-TOF-MS (Maxis, Bruker) (column $2.1 \times 50 \mathrm{~mm}, 1.7 \mu \mathrm{m}, \mathrm{C} 18$ Acquity UPLC BEH (Waters), solvent A: $\mathrm{H}_{2} \mathrm{O}+0.1 \%$ formic acid, solvent $\mathrm{B}: \mathrm{ACN}+0.1 \%$ formic acid, gradient: $5 \%$ B for $0.5 \mathrm{~min}$ increasing to $100 \%$ B in $19.5 \mathrm{~min}$, maintaining $100 \%$ B for another $5 \mathrm{~min}$, $\mathrm{RF}=0.6 \mathrm{~mL} \mathrm{~min}^{-1}, \mathrm{UV}$ detection 200-600 nm). NMR spectra were recorded on a Bruker Avance III $700 \mathrm{MHz}$ spectrometer with a $5 \mathrm{~mm}$ TCI cryoprobe $\left({ }^{1} \mathrm{H} 700 \mathrm{MHz},{ }^{13} \mathrm{C} 175 \mathrm{MHz},{ }^{15} \mathrm{~N} 71 \mathrm{MHz}\right)$. Chemical shifts $\delta$ were referenced to DMSO- $d_{6}\left({ }^{1} \mathrm{H}, \delta=2.50 \mathrm{ppm} ;{ }^{13} \mathrm{C}, \delta=39.51 \mathrm{ppm}\right)$. UV spectra were recorded using the Shimadzu UVvis spectrophotometer UV-2450. Optical rotation was determined using a PerkinElmer 241 polarimeter. Preparative isolation of the major components was achieved with preparative HPLC-system Gilson PLc 2250 (C18 column-nucleodur-7 $\mu \mathrm{m}-125 \times 40$ mm-RP 100, using Solvent $\mathrm{A}: \mathrm{H}_{2} \mathrm{O}$, solvent $\mathrm{B}$ : acetonitrile, gradient system: $20 \% \mathrm{~B}$ for $0.5 \mathrm{~min}$ increasing to $50 \% \mathrm{~B}$ in $30 \mathrm{~min}, 50 \%$ B to $100 \% \mathrm{~B}$ for $20 \mathrm{~min}$, maintaining $100 \%$ B for $5 \mathrm{~min}$, flow rate $=50 \mathrm{~mL} / \mathrm{min}$, detection at $200-600 \mathrm{~nm}$ ). 


\subsection{Strain Maintenance}

Streptomonospora sp. DSM 106425T was isolated in 2017 by the serial dilution method from a sand sample that had been collected from a beach of the North Sea at Cuxhaven, Germany. The strain grew well in the presence of $7 \% \mathrm{NaCl}$. This percentage of sodium chloride was added to all media that we used for culturing and production media. A section of the agar containing bacterial colonies and aerial mycelium was stored in glycerol $20 \%$ at $-80{ }^{\circ} \mathrm{C}$. The strain was transferred to $100 \mathrm{~mL}$ of liquid GYM medium $\left(0.4 \%\right.$ glucose, $0.4 \%$ yeast extract, $1 \%$ malt extract, $\left.0.2 \% \mathrm{CaCO}_{3} ; \mathrm{pH} 7.2\right)$. The inoculated flask was incubated on a rotary shaker $(160 \mathrm{rpm})$ for 5 days at $30^{\circ} \mathrm{C}$.

\subsection{Fermentation, Extraction, and Isolation of Compounds}

The 5-day-old preculture was transferred to production medium 1:10 in eight 1000-mL flasks, filled with $800 \mathrm{~mL}$ of medium 5294 (1\% soluble starch, $0.2 \%$ yeast extract, $1 \%$ glucose, $1 \%$ glycerol, $0.25 \%$ corn steep liquor, $0.2 \%$ peptone, $0.1 \% \mathrm{NaCl}, 0.3 \% \mathrm{CaCO}_{3} ; \mathrm{pH} 7.2$ ) incubated at $30{ }^{\circ} \mathrm{C}$ for 8 days on rotary shaker $(160 \mathrm{rpm})$. The 8 -day-old culture medium was centrifuged using a Sorvall RC-5 refrigerated superspeed centrifuge for $30 \mathrm{~min}$, at $8500 \mathrm{rpm}$. The supernatant was discarded and $311 \mathrm{~g}$ cell mass was extracted with two liters of acetone three time in an ultrasonic bath $(3 \times 30 \mathrm{~min})$. The solution obtained was evaporated to yield an aqueous phase, which was further extracted with ethyl acetate $(3 \times 500 \mathrm{~mL})$ and the ethyl acetate portion was dried out with evaporator to yield $575.2 \mathrm{mg}$ of crude cell mass extract. An initial pre-separation of $575.2 \mathrm{mg}$ crude extract was applied with a Strata TM-X 33 UM Polymeric reversed phase $1 \mathrm{~g} / 12 \mathrm{~mL}$ Giga tube (Phenomenex) and washed three times with methanol. Subsequently, fractionation of $265.2 \mathrm{mg}$ crude extract was completed by preparative HPLC (Gilson) (1 run using a linear gradient of solvent B from $20 \%$ to $50 \%$ solvent B in $30 \mathrm{~min}, 50 \%$ to $100 \% \mathrm{~B}$ in $20 \mathrm{~min}$ followed by isocratic conditions for $10 \mathrm{~min}$ at a flow rate of $50 \mathrm{~mL} / \mathrm{min}$ ). Fractions were collected and combined according to UV absorption at 220, 280 and $350 \mathrm{~nm}$ and yielded $5.6 \mathrm{mg}$ of 1 at a retention time of $37.5-38.5 \mathrm{~min}$ and $0.5 \mathrm{mg}$ of 2 at $36.5-37 \mathrm{~min}$, respectively.

Litoralimycin A (1): light-yellow oil; $[\alpha]_{\mathrm{D}}=+251\left(c=1 \mathrm{mg} / \mathrm{mL}\right.$ in acetone); ${ }^{1} \mathrm{H}$ NMR $(700 \mathrm{MHz}$, DMSO- $\left.d_{6}\right)$ : see Table $1 ;{ }^{13} \mathrm{C}$ NMR (175 MHz, DMSO- $\left.d_{6}\right)$ : see Table 1; ESI-MS: $m / z 1120.38[\mathrm{M}+\mathrm{H}]^{+}$, $1118.43[\mathrm{M}+\mathrm{H}]^{+} ;$HRESIMS: $m / z 1120.2429[\mathrm{M}+\mathrm{H}]^{+}$(calcd. for $\mathrm{C}_{48} \mathrm{H}_{46} \mathrm{~N}_{15} \mathrm{O}_{10} \mathrm{~S}_{4} 1120.2429$ ), 1142.2246 $[\mathrm{M}+\mathrm{Na}]^{+}$(calcd. for $\mathrm{C}_{48} \mathrm{H}_{45} \mathrm{~N}_{15} \mathrm{O}_{10} \mathrm{~S}_{4} \mathrm{Na}$ 1142.2249).

Litoralimycin B (2): light-yellow oil; $[\alpha]_{\mathrm{D}}=+399\left(c=1 \mathrm{mg} / \mathrm{mL}\right.$ in acetone); ${ }^{1} \mathrm{H}$ NMR $(700 \mathrm{MHz}$, DMSO- $d_{6}$ ): $\delta_{\mathrm{H}} 10.67$ (br s, 43-NH), 9.81 (br s, 21-NH), 9.74 (br s, 31-NH), 9.69 (br s, 28-NH), 8.95 (dd, $J=6.2,5.2 \mathrm{~Hz}, 10-\mathrm{NH}), 8.75(\mathrm{br} \mathrm{d}, J=8.2 \mathrm{~Hz}, 15-\mathrm{NH}), 8.52(\mathrm{~d}, J=8.2 \mathrm{~Hz}, 39-\mathrm{H}), 8.45(\mathrm{~s}, 2-\mathrm{H}), 8.31$ (s, 23-H), $8.29(\mathrm{~s}, 17-\mathrm{H}), 8.25(\mathrm{~s}, 12-\mathrm{H}), 8.22(\mathrm{~d}, J=8.2 \mathrm{~Hz}, 40-\mathrm{H}), 8.17\left(\mathrm{br} \mathrm{s}, 44-\mathrm{NH}_{\mathrm{a}}\right), 8.07(\mathrm{br} \mathrm{d}, J=9.2$ $\mathrm{Hz}, 5-\mathrm{NH}), 7.66\left(\mathrm{br} \mathrm{s}, 44-\mathrm{NH}_{\mathrm{b}}\right), 6.58\left(\mathrm{~s}, 45-\mathrm{H}_{\mathrm{a}}\right), 6.52(\mathrm{q}, J=6.9 \mathrm{~Hz}, 26-\mathrm{H}), 6.48$ (br s, 30- $\left.\mathrm{H}_{\mathrm{a}}\right), 5.81$ (br $\left.\mathrm{s}, 45-\mathrm{H}_{\mathrm{b}}\right), 5.72\left(\mathrm{br} \mathrm{s}, 30-\mathrm{H}_{\mathrm{b}}\right), 5.63\left(\mathrm{br} \mathrm{s}, 35-\mathrm{H}_{\mathrm{a}}\right), 5.44(\mathrm{~m}, 15-\mathrm{H}), 5.42\left(\mathrm{br} \mathrm{s}, 35-\mathrm{H}_{\mathrm{b}}\right), 4.70(\mathrm{dd}, J=15.9$, $\left.6.2 \mathrm{~Hz}, 10-\mathrm{H}_{\mathrm{a}}\right), 4.54\left(\mathrm{dd}, J=15.9,5.2 \mathrm{~Hz}, 10-\mathrm{H}_{\mathrm{b}}\right), 4.37(\mathrm{dd}, J=9.2,7.3 \mathrm{~Hz}, 5-\mathrm{H}), 2.64\left(\mathrm{~s}, 36-\mathrm{H}_{3}\right), 2.10$ $(\mathrm{dspt}, J=7.2,6.9 \mathrm{~Hz}, 7-\mathrm{H}), 1.79\left(\mathrm{br} \mathrm{d}, J=6.9 \mathrm{~Hz}, 27-\mathrm{H}_{3}\right), 1.55\left(\mathrm{br} \mathrm{d}, J=6.9 \mathrm{~Hz}, 20-\mathrm{H}_{3}\right), 0.90(\mathrm{~d}, J=6.9$ $\left.\mathrm{Hz}, 9-\mathrm{H}_{3}\right), 0.87\left(\mathrm{~d}, J=6.9 \mathrm{~Hz}, 8-\mathrm{H}_{3}\right) \mathrm{ppm} ;{ }^{13} \mathrm{C}$ NMR $\left(175 \mathrm{MHz}, \mathrm{DMSO}-d_{6}\right): \delta_{\mathrm{C}} 173.6(\mathrm{C}, \mathrm{C}-16), 170.9$ (C, C-6), 168.6 (C, C-11), 167.3 (C, C-22), 164.9 (C, C-44), 163.8 (C, C-1), 161.2 (C, C-42), 159.98 (C, C-4), 159.94 (C, C-14), 159.2 (C, C-19), 158.9 (C, C-25), 155.6 (C, C-32), 150.2 (C, C-33), 149.22 (C, C-3), 149.18 (C, C-41), 148.7 (C, C-18), 148.6 (2xC, C-13, C-24), 147.7 (C, C-37), 141.2 (CH, C-39), 133.8 (C, C-28), 133.6 (C, C-43), 133.1 (C, C-34), 130.6 (C, C-38), 129.2 (C, C-21), 129.0 (C, C-31), 128.3 (CH, $\mathrm{C}-26), 125.3(\mathrm{CH}, \mathrm{C}-12), 125.1(\mathrm{CH}, \mathrm{C}-17), 125.0(\mathrm{CH}, \mathrm{C}-23), 104.5\left(\mathrm{CH}_{2}, \mathrm{C}-30\right), 102.5\left(\mathrm{CH}_{2}, \mathrm{C}-45\right)$, $58.2(\mathrm{CH}, \mathrm{C}-5), 46.9(\mathrm{CH}, \mathrm{C}-15), 40.0\left(\mathrm{CH}_{2}, \mathrm{C}-10\right), 30.7(\mathrm{CH}, \mathrm{C}-7), 20.6\left(\mathrm{CH}_{3}, \mathrm{C}-20\right), 19.3\left(\mathrm{CH}_{3}, \mathrm{C}-8\right)$, $18.4\left(\mathrm{CH}_{3}, \mathrm{C}-9\right), 14.2\left(\mathrm{CH}_{3}, \mathrm{C}-27\right), 11.6\left(\mathrm{CH}_{3}, \mathrm{C}-26\right)$; ESI-MS: $\mathrm{m} / z$ 1051.32 [M + H] $]^{+}, 1049.34[\mathrm{M}+\mathrm{H}]^{+}$;

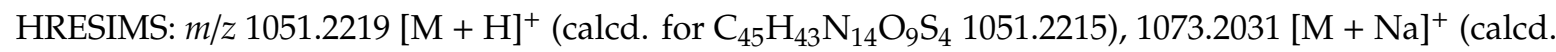
for $\mathrm{C}_{45} \mathrm{H}_{42} \mathrm{~N}_{14} \mathrm{O}_{9} \mathrm{~S}_{4} \mathrm{Na}$ 1073.2034). 


\subsection{Ozonolysis, Hydrolysis and Marfey's Derivatization with L-FDAA}

For the ozonolysis reaction a stream of $\mathrm{O}_{3}$ was bubbled through a solution of $\mathbf{1}(2.3 \mathrm{mg})$ dissolved in methanol $(6 \mathrm{~mL})$ at $-78^{\circ} \mathrm{C}$ until the solution obtained a characteristic blue color and stirred for $30 \mathrm{~min}$. Subsequently, the solvent was removed in vacuo and the resulting oxidized material was subjected to hydrolysis in $3 \mathrm{~mL}$ of $6 \mathrm{~N} \mathrm{HCl}$ at $110^{\circ} \mathrm{C}$ for $24 \mathrm{~h}$ as described in [6]. Afterwards, the solvent was removed under a stream of nitrogen for $3 \mathrm{~h}$ and the remainder dissolved in $\mathrm{H}_{2} \mathrm{O}(200 \mu \mathrm{L})$, of which $100 \mu \mathrm{L}$ were proceeded further. A total of $1 \mathrm{~N} \mathrm{NaHCO} 3(20 \mu \mathrm{L})$ and 1\% 1-fluoro-2,4-dinitrophenyl-5-Lalaninamide (100 $\mu \mathrm{L}$ in acetone) were added, and the mixture was heated at $40{ }^{\circ} \mathrm{C}$ for $40 \mathrm{~min}$ [17]. After being cooled to room temperature, the solutions were neutralized with $2 \mathrm{~N} \mathrm{HCl}(20 \mu \mathrm{L})$ and evaporated to dryness. The residues were dissolved in MeOH and analyzed by HPLC-MS. Retention times in minutes of FDAA-derivatized amino acids were 6.5 for Val and 5.0 for Ala. Retention times of the authentic amino acid standards were L-Val 6.5, DL-Val 6.5/7.5, L-Ala 5.0, DL-Ala 5.0/6.0.

\subsection{Minimum Inhibitory Concentrations}

Minimum Inhibitory Concentrations (MIC) were investigated in a serial dilution assay in 96-well microtiter plates in $\mathrm{YM}$ medium for yeasts and filamentous fungi and $\mathrm{BD}^{\mathrm{TM}}$ Difco ${ }^{\mathrm{TM}}$ Müller-Hinton Broth for bacteria, as previously published [18].

\subsection{Cytotoxicity Assay}

The in vitro cytotoxicity assay was carried out as described earlier [8].

\subsection{HPLC Fractionation and Bioassays in 96-Well Plates}

An Agilent 1260 Series HPLC-UV system equipped with a Waters, XBridge BEHC18, $2.1 \mathrm{~mm}$ $100 \mathrm{~mm}$ column (pore size $135 \AA$, particle size $3.5 \mu \mathrm{m}$, solvent A: $\mathrm{H}_{2} \mathrm{O}$-acetonitrile $(95 / 5), 5 \mathrm{mmol} \mathrm{NH}_{4} \mathrm{Ac}$, $0.04 \mathrm{~mL} / \mathrm{L} \mathrm{CH}_{3} \mathrm{COOH}$; solvent $\mathrm{B}: \mathrm{H}_{2} \mathrm{O}$-acetonitrile (5/95), $5 \mathrm{mmol} \mathrm{NH}{ }_{4} \mathrm{Ac}, 0.04 \mathrm{~mL} / \mathrm{L} \mathrm{CH}_{3} \mathrm{COOH}$; gradient system: $10 \% \mathrm{~B}$ increasing to $100 \% \mathrm{~B}$ in $30 \mathrm{~min}$; flow rate $0.3 \mathrm{~mL} / \mathrm{min} ; 40{ }^{\circ} \mathrm{C}$; UV-detection at $210-450 \mathrm{~nm}$ ) was used for the chromatographic fractionation of crude extracts. The same HPLC gradient was used as for the high-resolution electrospray ionization mass spectrometry (HRESIMS) instrument. The flow-through was collected in $30 \mathrm{~s}$ intervals into a 96-well microtiter plate. Afterwards, the plates were dried by a constant nitrogen-flush for $40 \mathrm{~min}$, inoculated with $150 \mathrm{~mL}$ indicator bacteria per well and incubated as described [17]. After $24 \mathrm{~h}$ the plates were evaluated and documented employing a custom-made mirror stand and a CANON EOS 60D digital camera.

\section{Conclusions}

Two new thiopeptide antibiotics were isolated from a new actinomycetes bacterium, which was isolated from a sand sample collected at a Wadden Sea beach. While their planar structures were elucidated by NMR and MS data, their absolute configuration was determined by degradation by ozonolysis and hydrolosis followed by Marfey's method. Their spectrum of biological activities is rare, because they are cytotoxic but possess virtually no antibacterial activities.

Supplementary Materials: The following are available online at http://www.mdpi.com/1660-3397/18/6/280/s1, Figure S1: Fractionation analysis of Streptomonospora sp. M2 crude extract. Table S1: Antimicrobial activity of 1 and 2, Figure S2: Observed TOCSY, HMBC and ROESY correlations for 1, Figure S3: Known compounds structurally related to litoralimycins, Figure S4: HPLC-MS and UV-Vis chromatograms of Streptomonospora sp. M2 and HRESIMS data, Figure S5: HPLC-ESIMS spectrum of litoralimycin A (1), Figure S6: ${ }^{1} \mathrm{H}$ NMR spectrum $\left(700 \mathrm{MHz}, \mathrm{DMSO}-d_{6}\right)$ of litoralimycin A (1), Figure S7: ${ }^{13} \mathrm{C}$ NMR spectrum $\left(175 \mathrm{MHz}, \mathrm{DMSO}-d_{6}\right)$ of litoralimycin A (1), Figure S8: COSY NMR spectrum (700 MHz, DMSO- $\left.d_{6}\right)$ of litoralimycin A (1), Figure S9: ROESY NMR spectrum (700 MHz, DMSO- $d_{6}$ ) of litoralimycin A (1), Figure S10: HSQC NMR spectrum (700 MHz, DMSO- $\left.d_{6}\right)$ of litoralimycin A (1), Figure S11: HMBC NMR spectrum (700 MHz, DMSO- $d_{6}$ ) of litoralimycin A (1), Figure S12: Marfey derivatization for determination of type and configuration of amino acids in litoralimycin A (1), Figure S13: HPLC-ESIMS spectrum of litoralimycin B (2), Figure S14: ${ }^{1} \mathrm{H}$ NMR spectrum $\left(700 \mathrm{MHz}, \mathrm{DMSO}-d_{6}\right)$ of litoralimycin B (2), Figure S15: ${ }^{13} \mathrm{C}$ NMR spectrum (175 MHz, DMSO- $\left.d_{6}\right)$ of litoralimycin B (2), Figure S16: 
COSY NMR spectrum (700 MHz, DMSO- $\left.d_{6}\right)$ of litoralimycin B (2), Figure S17: ROESY NMR spectrum $(700 \mathrm{MHz}$, DMSO- $d_{6}$ ) of litoralimycin B (2), Figure S18: HSQC NMR spectrum (700 MHz, DMSO- $d_{6}$ ) of litoralimycin B (2), Figure S19: HMBC NMR spectrum $\left(700 \mathrm{MHz}, \mathrm{DMSO}-d_{6}\right)$ of litoralimycin B (2), Figure S20: MS/MS data for 1 and 2 with fragmentation of $[\mathrm{M}+\mathrm{Na}]^{+}$ions.

Author Contributions: Conceptualization, J.W. and F.S.; execution of experiments, S.K.; structure elucidation, F.S.; resources, M.S.; writing-original draft preparation, S.K.; writing-review and editing, M.S., J.W., F.S.; supervision, J.W., F.S.; funding acquisition, M.S., J.W. All authors have read and agreed to the published version of the manuscript.

Funding: This research was funded by a personal stipend to S.K.

Acknowledgments: We would also like to thank Klaus-Peter Conrad for the measurement of HRESIMS data, Wera Collisi for conducting the bioassays, and Christel Kakoschke for the measurement of NMR spectra. We gratefully acknowledge the assistance of Romy Schade in cultivation of the strain and Silke Reinecke for helping to isolate the metabolites.

Conflicts of Interest: The authors declare no conflict of interest.

\section{References}

1. Stadler, M.; Dersch, P. How to overcome the antibiotic crisis-Facts, challenges, technologies \& future perspectives. Curr. Top Microbiol. Immunol. 2017, 398, 496.

2. Genilloud, O. Actinomycetes: Still a source of novel antibiotics. Nat. Prod. Rep. 2017, 34, 1203-1232. [CrossRef] [PubMed]

3. Tiwari, K.; Gupta, R.K. Rare actinomycetes: A potential storehouse for novel antibiotics. Crit. Rev. Biotechnol. 2012, 32, 108-132. [CrossRef] [PubMed]

4. Landwehr, W.; Wolf, C.; Wink, J. Actinobacteria and myxobacteria-Two of the most important bacterial resources for novel antibiotics. In How to Overcome the Antibiotic Crisis; Springer: Cham, Switzerland, 2016; pp. 273-302.

5. Subramani, R.; Aalbersberg, W. Culturable rare Actinomycetes: Diversity, isolation and marine natural product discovery. Appl. Microbiol. Biotechnol. 2013, 97, 9291-9321. [CrossRef] [PubMed]

6. Yun, B.-S.; Fujita, K.; Furihata, K.; Seto, H. Absolute stereochemistry and solution conformation of promothiocins. Tetrahedron 2001, 57, 9683-9687. [CrossRef]

7. Marfey, P.; Ottensen, M. Determination of D-amino acids. I. Hydrolysis of DNP-L-amino acid methyl esters with carboxypeptidase-Y. Carlsberg Res. Commun. 1984, 49, 585-590. [CrossRef]

8. Surup, F.; Halecker, S.; Nimtz, M.; Rodrigo, S.; Schulz, B.; Steinert, M.; Stadler, M. Hyfraxins A and B, cytotoxic ergostane-type steroid and lanostane triterpenoid glycosides from the invasive ash dieback ascomycete Hymenoscyphus fraxineus. Steroids 2018, 135, 92-97. [CrossRef] [PubMed]

9. Shen, X.; Mustafa, M.; Chen, Y.; Cao, Y.; Gao, J. Natural thiopeptides as a privileged scaffold for drug discovery and therapeutic development. Med. Chem. Res. 2019, 28, 1063-1098. [CrossRef]

10. Just-Baringo, X.; Albericio, F.; Álvarez, M. Thiopeptide antibiotics: Retrospective and recent advances. Mar. Drugs 2014, 12, 317-351. [CrossRef]

11. Malcolmson, S.J.; Young, T.S.; Ruby, J.G.; Skewes-Cox, P.; Walsh, C.T. The posttranslational modification cascade to the thiopeptide berninamycin generates linear forms and altered macrocyclic scaffolds. Proc. Natl. Acad. Sci. USA 2013, 110, 8483-8488. [CrossRef] [PubMed]

12. Lentzen, G.; Klinck, R.; Matassova, N.; Aboul-ela, F.; Murchie, A.I.H. Structural Basis for Contrasting Activities of Ribosome Binding Thiazole Antibiotics. Chem. Biol. 2003, 10, 769-778. [CrossRef]

13. González Holgado, G.; Castro Rodríguez, J.; Cañedo Hernández, L.M.; Díaz, M.; Fernández-Abalos, J.M.; Trujillano, I.; Santamaría, R.I. Radamycin, a novel thiopeptide produced by Streptomyces sp. RSP9. I. Taxonomy, fermentation, isolation and biological activities. J. Antibiot. 2002, 55, 383-390. [CrossRef] [PubMed]

14. Castro Rodríguez, J.; González Holgado, G.; Santamaría Sánchez, R.I.; Cañedo, L.M. Radamycin, a novel thiopeptide produced by Streptomyces sp. RSP9. II. Physico-chemical properties and structure determination. J. Antibiot. 2002, 55, 391-395. [CrossRef] [PubMed]

15. Chiu, M.L.; Folcher, M.; Katoh, T.; Puglia, A.M.; Vohradsky, J.; Yun, B.S.; Seto, H.; Thompson, C.J. Broad spectrum thiopeptide recognition specificity of the Streptomyces lividans TipAL protein and its role in regulating gene expression. J. Biol. Chem. 1999, 274, 20578-20586. [CrossRef] [PubMed] 
16. Hegdem, N.S.; Sanders, D.A.; Rodriguez, R.; Balasubramanian, S. The transcription factor FOXM1 is a cellular target of the natural product thiostrepton. Nat. Chem. 2011, 3, 725-731. [CrossRef] [PubMed]

17. Viehrig, K.; Surup, F.; Harmrolfs, K.; Jansen, R.; Kunze, B.; Müller, R. Concerted action of P450 plus helper protein to form the amino-hydroxy-piperidone moiety of the potent protease inhibitor Crocapeptin. J. Am. Chem. Soc. 2013, 135, 16885-16894. [CrossRef] [PubMed]

18. Sandargo, B.; Michehl, M.; Praditya, D.; Steinmann, E.; Stadler, M.; Surup, F. Antiviral meroterpenoid rhodatin and sesquiterpenoids rhodocoranes A-E from the wrinkled peach mushroom, Rhodotus palmatus. Org. Lett. 2019, 21, 3286-3289. [CrossRef] [PubMed]

(C) 2020 by the authors. Licensee MDPI, Basel, Switzerland. This article is an open access article distributed under the terms and conditions of the Creative Commons Attribution (CC BY) license (http://creativecommons.org/licenses/by/4.0/). 